\title{
Total atrioventricular block in Lyme borreliosis
}

\section{(D) Jurica Petranović ${ }^{1 *}$ ORea Levicki', Olvan Barišić', Olle Raštegorac', OVladimir Dujmović', DDarko Počanić ${ }^{2}$}

'Požega General Hospital, Požega, Croatia

2University Hospital "Merkur", Zagreb, Croatia
RECEIVED:

September 12, 2019

ACCEPTED:

September 16, 2019

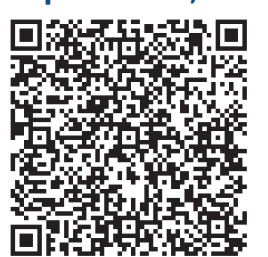

KEYWORDS: atrioventricular block, Lyme borreliosis.

CITATION: Cardiol Croat. 2019;14(9-10):251. | https://doi.org/10.15836/ccar2019.251

*ADDRESS FOR CORRESPONDENCE: Jurica Petranović, Dora Pfanova 7, HR-10000 Zagreb, Croatia. / Phone: +38591-1304-192 / E-mail: jura83@gmail.com

ORCID: Jurica Petranović, https://orcid.org/0000-0002-7129-0266 • Rea Levicki, https://orcid.org/0000-0003-3687-1310 Ivan Barišić, https://orcid.org/0000-0001-7397-7582 • Ile Raštegorac, https://orcid.org/0000-0002-2773-0957

Vladimir Dujmović, https://orcid.org/0000-0001-6545-9283 • Darko Počanić, https://orcid.org/0000-0003-3257-110X

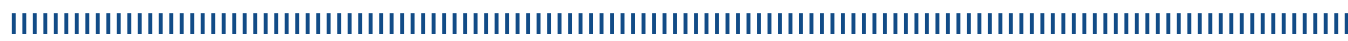

Introduction: Lyme disease is caused by the spirochete Borrelia Brugdorferi. It manifests as erythema migrans but can also cause central neuropathy, arthritis and carditis. ${ }^{1}$ Cardiac manifestations include conduction abnormalities with varying degrees of atrioventricular block and other rhythm disturbances. ${ }^{2}$ The incidence of Lyme disease increases from west to east across Europe, with the highest incidence in Slovenia $(155 / 100000){ }^{3}$

Case report: We observed a 32-year-old male patient who presented to the Emergency Department with recurrent syncope. Electrocardiography recorded intermittent total atrioventricular block, with an average heart rate of 25/min. A temporary pacemaker (Oscor Pace 101H, Single Chamber External Pacemaker) was implanted emergently using right jugular access. He had been on Sovsko lake near Čaglin village in Požega-Slavonia county 7 days prior to admittance, after which he had fever and chills for 2 days followed by diarrhea for 1 day. We started empirical treatment with intravenous ceftriaxone due to suspected Lyme disease. No tick bites on skin were found.

Results: Results of serological testing showed that IgM Lyme titer (ELISA) was positive >5.23, also CLIA IgM were positive (IgM >190, Ig G >240), followed by positive IgM and IgG Western Blot. Considering these results, we continued ceftriaxone treatment according to guidelines for 6 weeks. Echocardiography demonstrated normal left and right ventricular systolic function with no valvular dysfunction. First 3 days continuous pacing was required, afterwards for 7 days only intermittent pacing in night hours was required. In the end, the patient maintained normal sinus rhythm at 65-75 bpm. Two days after, the external pacemaker and active fixation lead was removed.

Conclusion: Lyme borreliosis infection can cause conduction abnormalities, including total atrioventricular block in structurally healthy heart. Conduction abnormalities are reversible with the use of proper antibiotic treatment.

LITERATURE IIIIIIIIIIIIIIIIIIIIIIIIIIIIIIIIIIIIIIIIIIIIIIIIIIIIIIIIIIIIIIIIIIIIIIIIIIIIIIIIIIIIIIIIIIIIIIIIIIIIIIIII

1. Forrester JD, Mead P. Third-Degree Heart Block Associated With Lyme Carditis: Review of Published Cases. Clin Infect Dis. 2014 0ct;59(7):9961000. https://doi.org/10.1093/cid/ciu411

2. Scheffold N, Herkommer B, Kandolf R, May AE. Lyme carditis--diagnosis, treatment and prognosis. Dtsch Arztebl Int. 2015 Mar 20;12(12):202-208 https://doi.org/10.3238/arztebl.2015.0202

3. Stanek G, Fingerle V, Hunfeld KP, Jaulhac B, Kaiser R, Krause A, et al. Lyme borreliosis: clinical case definitions for diagnosis and management in Europe. Clin Microbiol Infect. 2011 Jan;17(1):69-79. https://doi.org/10.1111/j.1469-0691.2010.03175.x 